$\begin{array}{lll}\text { KULTURA } & \begin{array}{l}\text { POLSKA AKADEMIA NAUK } \\ \text { KOMITET SOCJOLOGII }\end{array} & \text { ISSN 0023-5172 } \\ \text { i } & \begin{array}{l}\text { INSTYTUT ST UDIÓW POLITYCZNYCH } \\ \text { SPOLCZENSTWO }\end{array} & \\ \text { 2010, nr 4 } & \text { W STRONĘ PRZESZŁOŚCI } & \end{array}$

ŁUKASZ KRZYŻANOWSKI

Uniwersytet Warszawski

\title{
OBRAZKI Z PRL: PORTRET EPOKI WE WSPÓŁCZESNYM KINIE
}

PRL ze swoją historią jest obecny dziś nie tylko w dyskusjach historycznych i życiu politycznym. Również współczesna kultura popularna przywołuje wydarzenia i realia minionej epoki. We właściwy sobie sposób dokonuje syntezy historii i związanych z nią emocji, współtworząc popularną wiedzę o życiu w państwie demokracji ludowej. Od pewnego czasu odwołania do PRL-u można odnaleźć w reklamie, komiksach, hip-hopie, grach miejskich i kinie.

Kino jest medium kultury popularnej, które ma bardzo dużą moc formowania zbiorowej wyobraźni, wpływania na to, jak pamiętana jest przeszłość. Ciekawym przykładem udziału popkultury w tworzeniu i kształtowaniu pamięci społecznej są filmy, których akcja, lub jej część, dzieje się w czasie PRL. Zwłaszcza że obecnie w Polsce dochodzi do głosu nowe pokolenie reżyserów, często ledwie pamiętających końcowy okres Polski Ludowej lub znających go tylko $z$ rodzinnych wspomnień. Jednocześnie $w$ pełni sił twórczych pozostają filmowcy, którzy żyli w PRL-u i doskonale pamiętają tamte czasy. Wśród jednych i drugich znaleźć można twórców, którzy w ostatnim czasie zrealizowali obrazy odwołujące się do polskiej rzeczywistości przed rokiem 1989.

Nastąpił prawdziwy „wysyp” filmów o PRL-u. W ciągu półtora roku, od początku roku 2009 do połowy 2010, na ekrany weszło aż siedem produkcji fabularnych o Polskiej Rzeczpospolitej Ludowej. Choć po roku 1989 powstawały już podobne filmy (np. Kazimierza Kutza Śmierć jak kromka chleba, Zawrócony, Putkownik Kwiatkowski lub Cwat Krzysztofa Zanussiego), to zaryzykować można stwierdzenie, że PRL nigdy po zmianie ustrojowej nie budził takiego zainteresowania filmowców jak obecnie.

Adres do korespondencji: lukasz.krzyzanowski@gmail.com 
Warto przyjrzeć się, jakie elementy minionej epoki pojawiają się w powstających współcześnie filmach oraz $\mathrm{w}$ jaki sposób zostały one przedstawione. Kierunek poszukiwań może wskazać analiza treści obrazów filmowych, których premiery kinowe odbyły się w branym pod uwagę półtorarocznym okresie i których akcja (lub jej znaczna część) rozgrywa się w Polsce między rokiem $1945^{1}$ a 1989:

Popietuszko. Wolność jest w nas, scenariusz i reżyseria: Rafał Wieczyński, 2009, Generat Nil, scenariusz: Ryszard Bugajski, Krzysztof Łukaszewicz, reżyseria:

Ryszard Bugajski, 2009,

Wszystko, co kocham, scenariusz i reżyseria: Jacek Borcuch, 2009,

Rewers, scenariusz: Andrzej Bart, reżyseria: Borys Lankosz, 2009,

Dom zły, scenariusz: Wojciech Smarzowski, Łukasz Kośmicki, reżyseria:

Wojciech Smarzowski, 2009,

Różyczka, scenariusz: Jan Kidawa-Błoński, Maciej Karpiński, reżyseria: Jan Kidawa-Błoński, 2010,

Mistyfikacja, scenariusz i reżyseria: Jacek Koprowicz, 2010.

Trudno jest jednoznacznie odpowiedzieć na pytanie, dlaczego akurat teraz filmowcy tak chętnie wracają do minionej epoki. Być może jest to atrakcyjne dla młodego widza, wszak na całym świecie młodzi ludzie odczuwają nostalgię za czasami swoich dziadków. Nie można jednak twierdzić, że duże zainteresowanie filmowców PRL-em wynika bezpośrednio z wyjścia naprzeciw zapotrzebowaniom widzów. Innym wytłumaczeniem może być wiek samych filmowców - dzisiejsze czterdziestolatki wchodziły w dorosłość w czasach upadku socjalizmu w Polsce. Być może więc widzą PRL inaczej niż reżyserzy, którzy zdążyli dłużej pożyć w Polsce Ludowej. Należy jednak zauważyć, iż wśród twórców analizowanych przeze mnie filmów są również uznani filmowcy $z$ dużym dorobkiem, których trudno byłoby zaliczyć do grona młodych reżyserów. Możliwe, że przyczyn „mody na PRL w kinie” należy szukać zupełnie gdzie indziej. Niewykluczone, iż tematyka poruszana we współczesnym polskim kinie odzwierciedla ogólną atmosferę panującą w krajowej polityce i debatach publicznych. Innymi słowy, gdy odniesienia do Polski Ludowej dominują w życiu publicznym, to przenikają one również do rodzimej kinematografii. Powyższe przypuszczenia rzucają jedynie trochę światła na zarysowany fenomen popularności tematu PRL-u w polskim kinie końca pierwszej dekady XXI wieku. Być może, jak w przypadku wielu innych zjawisk, wyczerpujące wyjaśnienie będzie możliwe dopiero z perspektywy czasu.

Jak wspomniałem, powstające współcześnie filmy o PRL-u miały swoich poprzedników. Już w latach dziewięćdziesiątych kilku polskich reżyserów zdecydowało się na umieszczenie akcji swoich obrazów w Polsce Ludowej. Interesująca mogłaby być analiza porównawcza sposobów przedstawiania PRL-u

${ }^{1}$ Przyjęcie roku 1945 jako daty wyznaczającej początek PRL-u jest tu umowne. „Polska Rzeczpospolita Ludowa" to formalna nazwa państwa dopiero od $1952 \mathrm{r}$. 
w filmach powstałych zaraz po zmianie ustrojowej i w produkcjach współczesnych. W toku takiej analizy możliwe byłoby ukazanie postaw wobec minionej epoki zmieniających się przez ostatnich dwadzieścia lat i ewolucji pamięci o PRL-u. Jest to bardzo ciekawy temat, zasługujący na oddzielne opracowanie. Tutaj przyjrzę się jedynie obrazowi PRL-u, jaki wyłania się po obejrzeniu filmów z lat 2009-2010. Nie zamierzam systematyczne zestawiać „historii filmowej” $z$ „historią naukową” i wskazywać na ujawnione w ten sposób nieścisłości. Dużo ciekawszym zadaniem wydaje się próba wyodrębnienia najważniejszych elementów i tendencji w ukazywaniu przeszłości we współcześnie powstających obrazach filmowych ${ }^{2}$. Jest to istotne, gdyż z dużym prawdopodobieństwem można założyć, że mają one istotny wpływ na „popkulturowe myślenie" o najnowszej przeszłości Polski, kształtują pamięć zbiorową i znacząco wpływają na stosunek Polaków do minionej epoki. Popkultura decyduje o tym, które elementy PRL-u zostaną przypominane, a które odejdą w zapomnienie.

\section{KULTURA POPULARNA I HISTORIA PRL}

Kultura popularna jest obecnie „kulturą dominującą — nie tylko dlatego, że współcześnie to ona właśnie tworzy intersubiektywny świat (traktowany jako jedyna do pomyślenia realność), ale również dlatego, że pośredniczy w każdej innej próbie jego konstruowania, filtruje obce wobec niej znaczenia, reinterpretuje je i w podporządkowanej swojej logice formie upowszechnia, kreuje ramy interpretacji rzeczywistości, sankcjonuje drogi jej poznawania i działania w jej obrębie" 3 . Spostrzeżenie to odnosi się do wszystkich elementów wchodzących w skład współczesnej popkultury, a więc również do treści odwołujących się do najnowszej przeszłości Polski. Popkultura we właściwy sobie sposób opowiadając o PRL-u, jednocześnie wyznacza sposoby patrzenia na przeszłość. $\mathrm{W}$ ten sposób powstaje popularna wizja historii, która często jest bardziej atrakcyjna dla przeciętnego odbiorcy niż pisana hermetycznym językiem historia akademicka ${ }^{4}$.

Norman Davies w swojej historii Wysp Brytyjskich twierdzi, że „słysząc słowo «średniowieczny», większość ludzi próbowałaby w panice odszukać w pamięci coś, co wykraczałoby poza popularne telewizyjne parodie $\mathrm{w}$ rodzaju filmu

2 Analiza ta nie obejmuje filmów „Sceny faktu” Teatru Telewizji z tego okresu; na ten temat zob. M. Mazur, „Teatr Telewizji: «Scena faktu» — specyficzna wizja historii”, referat wygłoszony podczas Ogólnopolskiej Interdyscyplinarnej Konferencji Naukowej „Historie alternatywne” na Uniwersytecie Marii Curie-Skłodowskiej w Lublinie, 17-19 maja 2010.

${ }^{3}$ M. Krajewski, Kultury kultury popularnej, Wydawnictwo UAM, Poznań 2003.

${ }^{4} \mathrm{Na}$ problem nieprzystępnego języka i stylu wielu opracowań historycznych zwrócił uwagę Marcin Kula w wystąpieniu „Reportaż historyczny jako rodzaj współczesnej historiografii”, referat wygłoszony podczas Ogólnopolskiej Interdyscyplinarnej Konferencji Naukowej „Historie alternatywne" na Uniwersytecie Marii Curie-Skłodowskiej w Lublinie, 17-19 maja 2010 r. 
Monty Python i Święty Graal (którego akcja toczy się w bliżej nieokreślonym momencie XII wieku) lub serię Blackadder Rowana Atkinsona (którego akcja toczy się w bliżej nieokreślonym momencie wieku XIV lub XV)" 5 . Ta opinia znanego historyka nie tylko dobrze oddaje stosunek Brytyjczyków do ich odległej przeszłości, ale zawiera również ogólną prawdę dotyczącą wpływu filmowych obrazów na świadomość historyczną odbiorców. To dzięki filmom osadzonym w mniej lub bardziej wiernie oddanych realiach epoki żyjący dziś widzowie zyskują poczucie więzi oraz współuczestnictwa $\mathrm{w}$ dawnych, niekiedy bardzo odległych wydarzeniach ${ }^{6}$. Owa zależność jest w sposób oczywisty zauważalna w przypadku takich epok jak średniowiecze, ale występuje również w odniesieniu do mniej odległej przeszłości, takiej jak czasy PRL-u.

Wprawdzie żyje jeszcze wiele osób, które pamiętają Polskę Ludową, jednak w dorosłość wchodzi już pokolenie, którego wczesne dzieciństwo przypadło na ostatnie lata przed zmianą ustrojową roku 1989 albo wręcz na początek lat dziewięćdziesiątych. Swoją wiedzę o PRL-u ludzie owi mogą czerpać od rodziców i dziadków oraz ze szkoły. Oba te kanały — „rodzinny” oraz „edukacyjny” - w formie i w treści są często mało atrakcyjne. Alternatywne formy poznawania przeszłości to udział w grze miejskiej nawiązującej do realiów epoki Gierka, przeczytanie komiksu o strajkach robotniczych i Solidarności, albo właśnie pójście do kina.

Od początku 2009 r. na ekrany polskich kin weszło aż siedem wymienionych wcześniej filmów, których akcja, w całości lub w znaczącej części, rozgrywa się w Polsce Ludowej. Wśród tych produkcji można wyodrębnić dwie grupy obrazów:

(1) filmowe opowieści o życiu postaci historycznych,

(2) filmy fabularne osadzone $\mathrm{w}$ realiach PRL-u; w tej grupie istnieją co najmniej dwa różne sposoby korzystania z możliwości, jakie daje umieszczenie akcji filmu w Polsce Ludowej:

- PRL jest ważną osią opowiadanych losów mniej lub bardziej fikcyjnych bohaterów,

- PRL stanowi jedynie tło historii fikcyjnych bohaterów, a punkt ciężkości leży poza szeroko rozumianą polityką.

Szczególną uwagę poświęcę grupie drugiej. Autorzy filmów fabularnych, w których główne postacie są fikcyjne, mają większą wolność w zakresie doboru środków oraz kreowania swoich bohaterów. W takich produkcjach nie istnieje żaden historyczny wzorzec, który z góry określałby, jakie elementy minionej rzeczywistości muszą zostać pokazane w filmie. Dlatego analiza obrazów opowiadających o losach fikcyjnych bohaterów żyjących w PRL-u może powiedzieć więcej o widzeniu minionej epoki przez reżysera niż badanie fabuł

\footnotetext{
5 N. Davies, Wyspy. Historia, tłum. E. Tabakowska, Znak, Kraków 2003, s. 350.

${ }^{6}$ R. Marszałek, Filmowa pop-historia, Wydawnictwo Literackie, Kraków 1984, s. 15.
} 
filmowych, w których trudno oddzielić inwencję twórcy od próby naśladowania wydarzeń historycznych.

\section{„OBRAZY HISTORYCZNE” - GENERAŁ NIL I POPIEŁUSZKO}

Do pierwszej z wyróżnionych grup należą dwa filmy, które weszły na ekrany kin w 2009 r.: Popiełuszko. Wolność jest w nas w reżyserii Rafała Wieczyńskiego oraz Generat Nil w reżyserii Ryszarda Bugajskiego. Kanwą fabuły tych obrazów są losy ważnych postaci historycznych: zamordowanego przez SB kapelana Solidarności oraz dowódcy Kierownictwa Dywersji AK — ofiary stalinowskiej zbrodni sądowej.

Całość narracji w obu filmach ujęto w ramy „paradokumentalne” — widz jest świadkiem wydarzeń z życia głównych bohaterów. Oglądając je można się poczuć poruszonym losami księdza Popiełuszki i generała Fieldorfa. Jednak obrazy te nie skłaniają do refleksji, która wyszłaby poza konstatację: „tak, funkcjonariusze Polski Ludowej bezwzględnie tępili opozycję". Autorzy obu filmów tworzą ikony, pozbawiając swoich bohaterów wymiaru ludzkiego. Historyczne postacie i ich heroiczne czyny w ten sposób ulegają spłyceniu. Tomasz Raczek w recenzji z filmu Generat Nil przywołał określenie używane przez Zygmunta Kałużyńskiego - „msza narodowa” 7 , a Tadeusz Sobolewski film o Popiełuszce zaliczył do kategorii „śpiewów historycznych” uprawianych przez współczesną kinematografię polską ${ }^{8}$.

Oba filmy są jak reprodukcje scen batalistycznych na kartach podręcznika. Widz może odnieść wrażenie, że uczestniczy w lekcji historii, która opowiada o ludziach i wydarzeniach w bardzo schematyczny sposób - niezwykle trudno odnaleźć jakiekolwiek odcienie szarości. Stworzenie pełnowymiarowych postaci zapewne utrudniłoby objęcie tych produkcji wieloma oficjalnymi patronatami, przede wszystkim Instytutu Pamięci Narodowej i Narodowego Centrum Kultury. Filmowa opowieść o księdzu Popiełuszce zyskała również patronat Episkopatu, Prymasa, Metropolity Warszawskiego, Komisji Krajowej NSZZ Solidarność oraz specjalny „narodowy patronat” (sic!) Prezydenta RP.

Odwołanie do pedagogicznego wymiaru omawianych produkcji filmowych nie jest bezpodstawne. Premierom obu obrazów towarzyszyły kampanie edukacyjne. IPN stworzył nawet internetową „izbę pamięci”, w której najeżdżając kursorem na eksponaty, użytkownik może poznawać kolejne fakty z życia księdza Popiełuszki. Ze strony można pobrać również scenariusze lekcji oraz materiały dla nauczycieli języka polskiego, wiedzy o społeczeństwie oraz historii z gimnazjum i liceum. W oknie, w którym dostępne są pomoce dydaktyczne,

7 T. Raczek, Generał Nil — czytanka do ogladania, http://tomaszraczek.bloog.pl/id,4488317,title, General-Nil-czytanka-do-ogladania,index.html?ticaid=6acdc [31.08.2010].

8 T. Sobolewski, Jeden powód by zobaczyć film „Popiełuszko”, „Gazeta Wyborcza”, http://wyborcza. pl/1,75475,6323543,Jeden_powod_by_zobaczyc_film_Popieluszko_.html [18.08.2010]. 
można przeczytać, iż zostały one „przygotowane w ramach akcji społeczno-edukacyjnej Narodowego Centrum Kultury i Instytutu Pamięci Narodowej «Prawda jest nieśmiertelna - ks. Jerzy Popiełuszko»" 9.

Twórcy omawianych filmów zarówno z generała, jak i z kapłana próbują uczynić niemal komiksowych superbohaterów, przez co ich prawdziwe bohaterstwo traci na znaczeniu. Wszak do obowiązków superbohatera należy heroiczna postawa i nie ma w niej nic dziwnego. Próby wpisania godnych szacunku postaw generała Fieldorfa i księdza Popiełuszki w schemat popkultury można znaleźć także w plakatach promujących filmy. Na jednym $z$ afiszy reklamujących obraz Ryszarda Bugajskiego można było zobaczyć stryczek, na którym wisi Krzyż Orderu Wojennego Virtuti Militari. Z kolei do obejrzenia filmu o Popiełuszce zachęcał plakat łudząco podobny do afisza filmu Casino Royale o przygodach Jamesa Bonda z 2006 r. - zadziwiające podobieństwo kolorystyki, kompozycji oraz zdjęć na plakatach odkryli internauci ${ }^{10}$. Film Wieczyńskiego promowała także piosenka Nieśmiertelni zespołu Full Power Spirit. Utrzymany w stylu chrześcijańskiego hip-hopu utwór zawiera fragment archiwalnej wypowiedzi księdza Popiełuszki: „Za prawdę trzeba cierpieć, jestem przekonany, że to co robię jest słuszne, dlatego jestem gotowy na wszystko", oraz dodane od muzyków pouczenie: „Czas zresetować własny system wartości. Bóg, Honor, Ojczyzna, jak w czasach Solidarności” ${ }^{11}$.

Filmy o generale Fieldorfie i księdzu Popiełuszce należy uznać za obrazy edukacyjne, stanowiące przyczynek do budowania panteonu narodowych superbohaterów, $\mathrm{w}$ dodatku pod oficjalnymi patronatami. Jako takie mogą stanowić ciekawe źródło analiz dla naukowców zgłębiających tak zwaną „politykę historyczną". Występujące w nich elementy PRL służą ukazaniu opowiadanej historii w określonym świetle. Zawarty w nich obraz minionej epoki został zdeterminowany przez wybór postaci historycznych, o których filmy opowiadają, oraz intencje, jakie najwyraźniej przyświecały ich twórcom. Genarała Nila oraz Popietuszko. Wolność jest $w$ nas należy uznać za element szerszego zjawiska, jakim jest modelowanie pamięci zbiorowej o PRL-u, odgórne kształtowanie popkulturowego przekazu o tamtej epoce.

\section{HISTORIE FIKCYJNYCH BOHATERÓW W CZASACH PRL}

Obok dwóch wspomnianych obrazów, stanowiących próbę sfilmowania życiorysów prawdziwych, historycznych postaci, w tym samym czasie na ekrany polskich kin weszło aż pięć innych filmów, których akcja (lub jej znacząca część) rozgrywa się w czasach PRL-u. Przyjrzenie się wyłaniającej się z nich wizji tego

\footnotetext{
9 http://xj.popieluszko.pl/ [25.08.2010].

10 D. Subbotko, Ksiadz Popietuszko jak James Bond, „Gazeta Wyborcza”, http://wyborcza.pl/ 1,76842,6236858,Ksiadz_Popieluszko_jak_James_Bond.html [18.08.2010].

11 Tekst piosenki jest dostępny na stronie internetowej zespołu: http://fps.kdm.pl/ [25.08.2010].
} 
okresu jest tym ciekawsze, że reżyserzy i scenarzyści mieli dużą dowolność wyboru historii, którą chcieli opowiedzieć, a także środków.

Akcja wszystkich omawianych filmów rozgrywa się w momentach szczególnych w historii PRL-u: w szczytowych latach stalinizmu (Rewers), około roku 1968 (Różyczka, Mistyfikacja) czy w stanie wojennym (Wszystko, co kocham, Dom $z \nmid y)$. Umiejscowienie akcji w okresach przesileń politycznych sprawia, że historia PRL-u wchodzi w życie filmowych bohaterów. Należy jednak zauważyć, że realia PRL-u pełnią w pięciu analizowanych filmach różne funkcje. Od utrzymywania całej konstrukcji filmu (Różyczka, w dużym stopniu również Rewers i Mistyfikacja) do budowania scenerii, tła historii niezwiązanej z polityką (Wszystko, co kocham, Dom zty).

\section{PRL jako oś fikcyjnych historii — „świat agentów”}

Charakterystyczna dla wszystkich filmów z tej kategorii jest postać głównego lub jednego z głównych bohaterów - agenta komunistycznych tajnych służb. Oczywiście opowiadane historie różnią się od siebie, ale figura współpracownika UB lub SB jest obecna w Różyczce, Mistyfikacji i Rewersie.

Pojawiający się w filmach „bezpieczniacy” są bez wyjątku mężczyznami. Inwigilują opozycyjnych pisarzy (Różyczka, Mistyfikacja), nakłaniają do donoszenia na przełożonych i kochanków (Rewers, Różyczka). W pracy operacyjnej często posługują się szantażem i groźbami, chętnie również uwodzą kobiety, podejmując próby ich zwerbowania na tajnych współpracowników (Rewers, Ró$\dot{z} y c z k a)$. Pojawiające się w omawianych filmach postacie agentów często mają jakiś sekret. Może to być żydowskie pochodzenie skrywane w czasie antysemickiej nagonki roku 1968 (Różyczka) lub udział w bliżej nieokreślonej studenckiej opozycji i fascynacja postacią Witkacego (Mistyfikacja). Dzięki temu bohaterowie zyskują pewną głębię, choć ich losy nadal wydają się jedynie pretekstem do opowiedzenia historii, a nie jej tematem. Reżyserom omawianych filmów nie udaje się zbyt daleko odejść w tworzonej przez nich filmowej fikcji od faktów z życia prawdziwych osób. Świadczyć o tym mogą nawiązania w Mistyfikacji do życia i zagadkowej śmierci Jerzego Zawieyskiego ${ }^{12}$ lub próba zablokowania premiery Różyczki przez Ewę Beynar-Czeczott, która twierdziła, że film naraża na szwank dobre imię jej ojca ${ }^{13}$.

Dlaczego figura agenta odgrywa tak ważną rolę w trzech analizowanych tutaj filmach? Być może jest po prostu użyta jako narzędzie budowania potrzebnego w filmie napięcia, służy pokazaniu szczegółów relacji między różnymi posta-

\footnotetext{
12 Nie wiadomo, dlaczego autor nie zdecydował się na użycie fikcyjnego nazwiska. Nie miałoby to żadnego znaczenia z punktu widzenia opowiadanej historii.

13 Kidawa-Błoński: „Różyczka” nie jest filmem o Pawle Jasienicy, awe PAP, http://wiadomosci.gazeta. pl/Wiadomosci/1,80708,7623028,Kidawa_Blonski_Rozyczka_nie_jest_filmem_o_Pawle.html [31.08.2010].
} 
ciami. Może to być również konsekwencją klimatu panującego w dyskursie publicznym o PRL-u. Zaryzykuję twierdzenie, że w czasach gdy w debatach o komunistycznej przeszłości Polski dominuje poszukiwanie agentów, tendencja ta znajduje odzwierciedlenie również w produkcji filmowej.

\section{PRL jako tło historii fikcyjnych}

Dwa z analizowanych filmów opowiadają historie zwykłych ludzi żyjących w Polsce Ludowej. Dom zty Wojciecha Smarzowskiego i Wszystko, co kocham Jacka Borcucha bardzo różnią się od siebie fabułą, jednak łączy je potraktowanie PRL-u jako tła. Dom zły jest filmem pełnym napięcia. Jego akcja rozgrywa się podczas stanu wojennego na bieszczadzkim odludziu. Przyjazd obcego do wsi narusza ustalone relacje. Następuje brutalne zabójstwo. Podczas wizji lokalnej na miejscu zbrodni jeden $z$ milicjantów natrafia na trop malwersacji $\mathrm{w}$ pobliskiej cukrowni, zamieszani są $\mathrm{w}$ nią prokurator, milicjanci i miejscowy funkcjonariusz SB. Z kolei Wszystko, co kocham jest historią grupy licealistów dorastających na wybrzeżu na początku lat osiemdziesiątych. Tworzą zespół rockowy, zakochują się, piją tanie wina i przeżywają fascynację urodziwą sąsiadką. Ich rodziny w naturalny sposób są włączone w czasy, w których toczy się akcja filmu. Główny bohater ma ojca w marynarce wojennej, a jego dziewczyna należy do Solidarności. Polityka wchodzi w życie bohaterów, ale nie staje się ani głównym tematem filmu, jak w obrazach o generale Fieldorfie i księdzu Popiełuszce, ani nie jest jego główną osią, wokół której zbudowana została filmowa historia tak, jak w Różyczce.

Potraktowanie PRL-u jako tła, a nie figury, paradoksalnie pozwala na wydobycie wielu niuansów tamtej epoki. W filmie Wszystko, co kocham ukazana jest skomplikowana sytuacja rodziny, z jednej strony biorącej udział w opozycji, a $z$ drugiej zaangażowanej $w$ struktury komunistycznego państwa. O realiach PRL-u mówi on dużo więcej niż filmy, które powstały przede wszystkim jako obrazy historyczne.

Podobnie jest również w przypadku Domu złego. Realia polityczne uczestniczą tu w budowaniu nastroju grozy, ale nie są jego najważniejszym elementem. Akcja rozgrywa się w zimie, podczas stanu wojennego, kiedy utrudniona jest wszelka komunikacja, co sprawia, że dramat bohaterów rozgrywa się na jeszcze większym odludziu. Takie ujęcie pozwala na uchwycenie pewnych drobnych elementów codzienności PRL-u. W jednej ze scen filmu można zobaczyć milicjanta wyciągającego z bagażnika radiowozu „zdobyte” pół świniaka, w innej - kolejkę w sklepie GS-u i puste półki. We Wszystko, co kocham bohaterowie nie mogą zagrać koncertu na szkolnej zabawie, gdyż teksty ich piosenek nie zostały ocenzurowane.

Detale sygnalizujące realia epoki można odnaleźć również $\mathrm{w}$ filmach „penetrujących świat agentów”, ale jest ich tam mniej, jakby przesłaniała 
je polityka. W Mistyfikacji muza Witkacego (który w filmie żyje jeszcze w latach sześćdziesiątych) „sposobem” zdobywa w restauracji piwo - napój niedostępny $\mathrm{w}$ zwykłym sklepie. Z kolei w Rewersie główna bohaterka połyka monetę $\mathrm{w}$ obawie przed wykryciem, że nielegalnie przechowuje złoto.

Oba filmy, Dom zły i Wszystko, co kocham, traktując PRL jako scenerię, o rzeczywistości minionej epoki opowiadają poprzez detal. Opisana w nich historia, to nie historia przez wielkie „H”, dlatego możliwe jest bliższe ukazanie, jak bardzo trudne i niejednoznaczne były czasy, w których umieszczono losy skądinąd fikcyjnych postaci. Filmy te nie przedstawiają jednolitego obrazu epoki. Parafrazując tytuł artykułu Marcina Kuli można powiedzieć, że nieboszczka PRL nie jest $\mathrm{w}$ nich ani piękna, ani dobra... ale skomplikowana ${ }^{14}$.

\section{KRAJ, KTÓRY NIE TRZEŹWIAŁ}

Mimo różnic w obrazowaniu minionej epoki istnieje jeden element występujący w znakomitej większości współczesnych filmów o PRL-u (bez względu na to, czy ich bohaterowie są historyczni, czy też fikcyjni). Tym elementem peerelowskiej codzienności jest alkohol.

Pojawiający się na ekranie przedstawiciele komunistycznego aparatu władzy piją. Alkohol leje się strumieniami nie tylko na dansingach, ale również w pracy. Funkcjonariusze SB w Różyczce i Mistyfikacji piją koniak i wódkę podczas spotkań służbowych $z$ przełożonymi. Picie alkoholu to, obok prowadzenia śledztwa, jedno z głównych zajęć milicjantów w Domu ztym. Prokurator pojawiający się na miejscu zbrodni jest tak pijany, że nie może dokonać oględzin. W tym samym czasie milicjanci stoją w kolejce po bimber, nucąc hymn ZSRR. Tak budowany jest wizerunek upijających się „komunistycznych macho" — zabieg wyjątkowo wyrazisty w przypadku agenta SB z Różyczki.

Piją nie tylko przedstawiciele państwa - główny bohater Domu złego, zootechnik z PGR-u, upija się ze spotkanym gospodarzem. Podczas libacji obaj snują plany wspaniałego interesu, jaki można zrobić na sprzedaży bimbru „ruskim" stacjonującym w pobliskiej jednostce wojskowej.

To, jak ważne miejsce zajmuje alkohol $\mathrm{w}$ powstających współcześnie filmach, pokrywa się z funkcjonującymi w powszechnej świadomości opiniami na temat PRL-u. Przekonanie takie nie jest bezpodstawne. Od połowy lat sześćdziesiątych do końca PRL-u „statystyczny obywatel” w ciągu roku wydawał co najmniej jedną miesięczną pensję na napoje alkoholowe ${ }^{15}$.

14 M. Kula, Nieboszczka PRL. Ani dobra, ani mądra, ani piękna... ale skomplikowana, w: Spór o PRL, Znak, Kraków 1996, s. 104-110.

15 K. Kosiński, Historia pijaństwa w czasach PRL. Polityka - obyczaje - szara strefa - patologie, Neriton-IH PAN, Warszawa 2008, s. 388. 
Nasuwa się pytanie, dlaczego PRL we współczesnych filmach jest zwykle pijany albo chociaż na lekkim rauszu? Być może jest to sygnał, że Polskę Ludową trudno jest dziś zrozumieć „na trzeźwo”, więc opowiadając losy bohaterów żyjących w tamtym czasie dobrze jest umieścić butelkę wódki jako element entourage'u.

Współczesne kino, tak jak inne formy kultury popularnej w Polsce, nie zapomniało o PRL-u. Co więcej, nie można wskazać innego okresu polskiej historii, który w ostatnich latach zaznaczyłby swoją obecność w tak wielu filmach. Filmowcy sięgają jednak do PRL-u na bardzo różne sposoby.

Po pierwsze, należy wskazać, że powstają filmy takie jak Popiełuszko. Wolność jest $w$ nas i Generat Nil, które przynajmniej w założeniu opowiadają historię „taką, jaka była”, starają się trzymać faktów z życia postaci historycznych. W tym przypadku następuje wyraźna idealizacja bohaterów - tworzone są ikony, co skutkuje eliminacją niuansów i uproszczeniem opowiadanych historii. Wszystko to sprawia, że filmy, o których tu mowa, mogą być użyteczne podczas nauczania określonej wizji historii PRL-u — „komiksowej”, bez odcieni szarości. Można je uznać za przykład wykorzystania środków wyrazu, jakimi dysponuje popkultura, do modelowania pamięci zbiorowej o PRL-u.

Po drugie, wiele jest filmów fabularnych, których bohaterami są osoby fikcyjne, a PRL jest traktowany jako oś fabuły lub jako sceneria, tło akcji. Pierwszą tendencję reprezentują Różyczka, Rewers oraz Mistyfikacja. Dla konstrukcji tych filmów fakt umieszczenia ich akcji w Polsce Ludowej ma zasadnicze znaczenie. We wszystkich trzech obrazach, współczesny widz wprowadzany jest w świat agentów i donosicieli. W ten sposób możliwe jest „podglądanie” bohaterów oczyma funkcjonariuszy. Czy jest to jedyny powód, dla którego w krótkim czasie powstały aż trzy produkcje opowiadające o pracownikach tajnych służb? Być może tematyka tych filmów stanowi również odbicie atmosfery, jaka od pewnego czasu panuje w publicznym dyskursie o PRL-u. Drugi sposób wykorzystania scenerii przeszłości - traktowanie minionej epoki jako tła - reprezentują Wszystko, co kocham i Dom zły. Centrum akcji obu tych obrazów zostało umieszczone poza polityką, a Polska Ludowa jest obecna w życiu filmowych bohaterów w sposób „naturalny”. Co ciekawe, te produkcje mówią o realiach PRL-u dużo więcej, ukazują obraz bardziej zniuansowany niż filmowe biografie historycznych postaci czy opowieści z życia agentów tajnych służb. Nasuwa się wniosek, że potraktowanie PRL-u tak jak każdego innego okresu w historii Polski - jako tła, a nie tematu samego w sobie - może mieć pozytywny wpływ na wartość artystyczną dzieł filmowych. Przy okazji uchroni nas to przed tworzeniem kolejnych mitów, ikon i superbohaterów - tych chyba już wystarczy. 
PICTURES FROM THE PEOPLE'S REPUBLIC OF POLAND:

\section{IMAGE OF THE COMMUNIST PAST IN CONTEMPORARY POLISH CINEMA}

\section{Summary}

The article identifies main themes in the representations of PRL (People's Republic of Poland) in contemporary Polish cinema. The study is based on a qualitative analysis of seven movies from 2009 and the first half of 2010. The paper deals with a link between popular culture and social memory of communism in Poland.

\section{Key words/słowa kluczowe}

People's Republic of Poland / Polska Rzeczpospolita Ludowa (PRL); collective memory / pamięć zbiorowa; popular culture / kultura popularna; film / film 